\title{
Himalayan lapsi, Choerospondias axillaris (Roxb.) enhances concentration of vitamin $C$ in tissues of rohu (Labeo rohita $H$ ) cultured at Chitwan (Nepal)
}

\begin{abstract}
Labeo rohita lacks the enzyme for endogenous synthesis of vitamin $\mathrm{C}$ and lapsi fruits are rich in vitamin C. A study was conducted to examine the concentration of vitamin $\mathrm{C}$ in the blood serum, brain and liver of $L$. rohita through lapsi fruits extract supplemented in the diets. Six groups of $L$. rohita were fed experimental diets containing lapsi fruits extract supplemented at $0 \mathrm{mg} \mathrm{kg}^{-1}$ (D1), $100 \mathrm{mg} \mathrm{kg}^{-1}$ (D2), $200 \mathrm{mg} \mathrm{kg}^{-1}$ (D3), $400 \mathrm{mg} \mathrm{kg}^{-1}$ (D4), $800 \mathrm{mg} \mathrm{kg}^{-1}$ (D5) and $1600 \mathrm{mg} \mathrm{kg}^{-1}$ (D6) for 90 days. Growth parameters (WG, SGR and FCR) and Vitamin $\mathrm{C}$ concentration in blood serum, brain and liver were evaluated during the experimental trial. Carps fed with a lapsi fruits extract supplemented diet showed higher specific growth rate (SGR) compared with control diet fed carps. Results from this study help to establish the beneficial effect of vitamin $\mathrm{C}$ rich lapsi fruits on growth and immunmodulation in rohu. It can be concluded that lapsi fruits extract supplemented diet can be used to improve the immune system of $L$. rohita as indicated by enhancement of vitamin $\mathrm{C}$ in the serum, brain and the liver.
\end{abstract}

Keywords: growth, vitamin c, brain, liver, serum, choerospondias axillaris, labeo rohita
Volume 4 Issue 3 - 2018

\author{
Shubha Ratna Shakya, Shyam Narayan Labh \\ Department of Zoology, Tribhuvan University, Nepal
}

Correspondence: Shubha Ratna Shakya, Department of Zoology, Amrit campus, Tribhuvan University, Kathmandu, Nepal, Email shubharatnashakya@gmail.com

Received: May 01, 2018 | Published: June 19, 2018

\section{Introduction}

Himalayan lapsi, Choerospondias axillaris (Roxb.) is native to Nepal and is also reported from south-east Asian countries. ${ }^{1}$ Its fruits containing vitamin $\mathrm{C}^{2}$ Phenol and flavonoid compounds ${ }^{3,4}$ are consumed to enhance the immunity ${ }^{5}$ and neutralize free radicals formed in the body. Vitamin $\mathrm{C}$ is required to form collagen, growth, reproduction, resist diseases and for immunity in many fishes. ${ }^{6}$ Oxygen present in air, high temperature, enzymes and multivalent cations destroy it. In the manufacturing process and storage of diet Vitamin C supplemented in it is lost. ${ }^{7}$ Many structural and functional abnormalities result in fishes due to insufficient supply of vitamin $\mathrm{C}^{8}{ }^{8}$ Teleost fishes like rohu lacking GLO enzyme ${ }^{9}$ needs supply of vitamin $\mathrm{C}$ along with the diet. ${ }^{10}$ Many researches on the effect of vitamin $\mathrm{C}$ on growth, its concentration in different tissues and stress overcome in fishes are available. ${ }^{11}$ But the work on the effect of lapsi extract on growth and its concentration in brain, liver and blood in L. rohita is not available.

\section{Materials and methods}

\section{Experimental design and set up}

About four hundred farm-raised fingerlings of Labeo rohita (3.2 $\pm 0.014 \mathrm{~g}$ ) were selected from the nursery pond and transferred them to the stocking pond for their proper acclimatization. Altogether six test diets D1 (0), D2 (100), D3 (200), D4 (400), D5 (800) and D6 (1600) were prepared along with other standard ingredients (Table 1). Eighteen rectangular nylon happas $(1 \mathrm{~m} \times 1.5 \mathrm{~m} \times 1 \mathrm{~m})$ were suspended in the experimental pond with ropes and bamboos. Two hundred seventy fingerlings of rohu $(2.32 \pm 0.017 \mathrm{~cm}$ and $3.43 \pm 0.113 \mathrm{~g})$ were selected and distributed in six treatment groups in triplicates. Fingerlings were fed with test and control diets at the rate of $3 \%$ of their body weight at 9 a.m. and 4 p.m for 90 days. Temperature was maintained between $25^{\circ} \mathrm{C}$ to $29^{\circ} \mathrm{C}$ and $\mathrm{pH}$ between 7.53 to 7.92 during experimental period. Every two weeks 5 fingerlings each happa were selected randomly and weighed to adjust the amount of feed to be given. The experiment was conducted in the ponds of Corona of Agriculture in Chitwan (Nepal).

\section{Preparation of ethanol extract of lapsi fruits}

The ethanol extract of the pulp of lapsi fruits was made by using $70 \%$ ethanol. ${ }^{4} 10 \mathrm{~g}$ of lapsi fruit powder was mixed with $500 \mathrm{ml}$ of $70 \%$ ethanol in a conical flask. The flask was sealed by cotton plug and aluminum foil and then kept in orbital shaker for $48 \mathrm{hrs}$. The mixture was then filtered. The filtrate was centrifuged at $10,000 \times \mathrm{g}$ for 5 minutes. The supernatant obtained was concentrated at $70{ }^{\circ} \mathrm{C}$ in water bath. Finally, a greasy substance (crude extract) of the lapsi fruit pulp was obtained and transferred to screw-cap bottle and stored at $4^{\circ} \mathrm{C}$ for future use.

\section{Formulation of feed and preparation of lapsi fruit extract supplemented diets}

One control diet D1 and five treated diets D2, D3, D4, D5 and D6 were prepared. The treated diets were supplemented with 100 , 200, 400, 800 and $1600 \mathrm{mg} \mathrm{kg}^{-1}$ lapsi fruit extracts respectively. Other standard ingredients were used during feed preparation (Table 1).

\section{Examination procedures}

\section{Growth measurements and survival}

Fingerlings were harvested after 24 hours of fasting. Final length and final weight of each individual carp were measured. Length gain (\%), weight gain (\%), specific growth rate (SGR), feed conversion ratio (FCR) and survival per cent were determined as follows:

$$
\begin{aligned}
& \mathrm{LG}(\%)=\text { Final length }- \text { Initial length } / \text { Initial length } \times 100 \\
& \mathrm{WG}(\%)=\text { Final weight }- \text { Initial weight } / \text { Initial weight } \times 100
\end{aligned}
$$




$$
\mathrm{SGR}=((\text { In Wf }- \text { In Wi })) / \mathrm{t} \times 100
$$

Where, 'Wi' and 'Wf' are the initial and final body weights and ' $\mathrm{t}$ ' the experimental days.

$$
\mathrm{FCR}=\mathrm{F} /(\mathrm{Wf}-\mathrm{Wo})
$$

Where ' $F$ ' is the weight of food supplied to fish during the experimental period; ' $\mathrm{W}_{\mathrm{o}}$, is the weight of live fish at the beginning of the experimental period; 'Wf' is the weight of live fish at the end of the experiment.

$$
\text { Survival }(\%)=N f / N i \times 100
$$

Where ' $\mathrm{Nf}$ 'is the number of fish harvested and ' $\mathrm{Ni}$ ' the initial number of fish.

\section{Blood and tissues collection}

Three fish were collected at random from each replicate of control and treated groups on $90^{\text {th }}$ day of the experiment. They were anaesthetized by $5 \mathrm{mg} \mathrm{L}^{-1}$ of MS-222 for 2-3 minutes. Blood samples were drawn from the caudal vein in sample collecting tubes $(2 \mathrm{ml})$ without ethylene diamine tetra acetic acid (EDTA) by a syringe with 25 gauge needle. The tubes were centrifuged for $5 \mathrm{~min}$ at $3000 \times \mathrm{g}$ and the supernatant serum was collected and stored at $-20^{\circ} \mathrm{C}$ for future use. Fingerlings were dissected properly to obtain tissues of brain and liver. The collected tissues were place in Eppendort tubes containing

Table I Composition of experimental diets (\%) showing various ingredients buffer and stored at $-4^{\circ} \mathrm{C}$ for further use.

\section{Vitamin C estimation in blood serum, brain and liver}

Vitamin $\mathrm{C}$ in the blood serum, tissues of brain and liver were estimated according to the method described by. ${ }^{12}$ Pre-weighed brain and liver tissues were homogenized in ice-cold $250 \mathrm{mM} \mathrm{HClO}_{4}$ containing 5\% trichloro acetic acid (TCA) and $0.08 \%$ EDTA. The homogenates were centrifuged at $27000 \mathrm{~g}$ for $30 \mathrm{~min}$ at $4^{\circ} \mathrm{C} .25 \mu \mathrm{l}$ of $0.2 \%$ dichloro phenolindo phenol (DCIP) were added to the 250 $\mu 1$ of deproteinised samples. The same amount was added to a blank and then the mixtures were incubated at $37^{\circ} \mathrm{C}$ for 1 hour. After that 25 $\mu 1$ of $1 \% \mathrm{KBrO}_{3}$ were added and mixtures were incubated at $37^{\circ} \mathrm{C}$ for further 1 hour. Then $250 \mu 1$ of $2 \%$ thiourea in $5 \%$ meta-phosphoric acid was added followed by an equal volume of $2 \%$ of 2, 4-dinitro phenyl hydrazine (DNPH) in $12 \mathrm{M} \mathrm{H}_{2} \mathrm{SO}_{4}$. All samples were incubated for 3 hour at $60^{\circ} \mathrm{C}$ after which $0.5 \mathrm{ml}$ of ice-cold $18 \mathrm{M} \mathrm{H}_{2} \mathrm{SO}_{4}$ were added. The samples were transferred into Eppendorf tubes and centrifuged at $11300 \mathrm{~g}$ for 3 minutes. The absorbance was recorded at $524 \mathrm{~nm}$ with a spectrophotometer. Standard $(20-200 \mu \mathrm{g} / \mathrm{ml})$ were prepared with vitamin C (1-ascorbic acid, HiMedia).

\section{Statistical analysis}

Value for each parameter measured has been expressed as mean \pm standard error of mean. One-way Analysis of Variance (ANOVA) was

\begin{tabular}{|c|c|c|c|c|c|c|}
\hline \multirow{2}{*}{ Ingredients $(\mathrm{g} / \mathrm{/00 \textrm {g } )}$} & \multicolumn{6}{|c|}{ Experimental diets (\% Inclusion) g/kg } \\
\hline & DI & D2 & D3 & D4 & D5 & D6 \\
\hline Fish Meal $^{\dagger}$ & 29.31 & 29.31 & 29.31 & 29.31 & 29.31 & 29.31 \\
\hline Soya Meal ${ }^{\ddagger}$ & 14.52 & 14.52 & 14.52 & 14.52 & 14.52 & 14.52 \\
\hline Groundnut oil cake ${ }^{\dagger}$ & 9.17 & 9.17 & 9.17 & 9.17 & 9.17 & 9.17 \\
\hline Rice Powder ${ }^{\dagger}$ & 14.16 & 14.16 & 14.16 & 14.16 & 14.16 & 14.16 \\
\hline Wheat Flour ${ }^{\dagger}$ & 14.43 & 14.43 & 14.43 & 14.43 & 14.43 & 14.43 \\
\hline Corn flour ${ }^{\dagger}$ & 11.37 & 11.37 & 11.37 & 11.37 & 11.37 & 11.37 \\
\hline Sunflower oil ${ }^{\dagger}$ & 3 & 3 & 3 & 3 & 3 & 3 \\
\hline Cod liver oil ${ }^{\dagger}$ & 2 & 2 & 2 & 2 & 2 & 2 \\
\hline Vitamin \& Mineral Premix ${ }^{\S}$ & I & 1 & 1 & I & 1 & I \\
\hline C. axillaris extract ${ }^{\dagger}$ & 0 & 0.01 & 0.02 & 0.04 & 0.08 & 0.16 \\
\hline Betain Hydrochloride†† & 0.02 & 0.02 & 0.02 & 0.02 & 0.02 & 0.02 \\
\hline $\begin{array}{l}\text { BHT(Butylated } \\
\text { hydroxytoluene) } \dagger \dagger\end{array}$ & 0.02 & 0.02 & 0.02 & 0.02 & 0.02 & 0.02 \\
\hline $\begin{array}{l}\text { CMC (Carboxymethyl } \\
\text { cellulose) } \dagger^{+}\end{array}$ & I & 0.99 & 0.98 & 0.96 & 0.92 & 0.84 \\
\hline Total & 100 & 100 & 100 & 100 & 100 & 100 \\
\hline
\end{tabular}
used to analyze the data followed by Duncan's Multiple Range Test ${ }^{13}$ to find the difference at $5 \%(\mathrm{P}<0.05)$ level.

†'Ingredients like fish meal, soya meal, groundnut oil cake, rice powder, wheat flour, corn flour, sunflower oil and Cod Liver Oil were procured from local market of Kathmandu Valley.

${ }^{\ddagger}$ Ruchi Soya Industries, Raigad, India.

$\S$ Composition of vitamin mineral mix (EMIX PLUS) (quantity $2.5 \mathrm{~kg}^{-1}$ )

Vitamin A 55,00,000 IU;Vitamin D I I,00,000 IU;Vitamin B 2,000 mg;Vitamin E 750 mg;Vitamin K I,000 mg;Vitamin B I,000 mg;Vitamin B 6 g; Calcium Pantothenate 2,500 mg; Nicotinamide $10 \mathrm{~g}$; Choline Chloride $150 \mathrm{~g}$; Mn 27,000 mg; I I,000 mg; Fe 7,500 mg; Zn 5,000 mg; Cu 2,000 mg; Co 450 mg; Ca 500 g; P $300 \mathrm{~g} ; \mathrm{L}-$ lysine 10 g; DL-Methionine $10 \mathrm{~g}$; Selenium $50 \mathrm{mgl}^{-1}$; Selenium $50 \mathrm{mgl}^{-1}$; Satwari $250 \mathrm{mgl}^{-1}$; (Lactobacillus 120 million units and Yeast Culture 3000 crore units).

†Fruits of C.Axillaris were obtained locally and then extracts were prepared from the pulp of lapsi fruits.

t†Himedia Laboratories, Mumbai, India. 


\section{Results}

\section{Growth measurements and Survival}

After the completion of the experiment cent per cent survival rate was observed in D4 and D5 fed groups followed by $97.78 \pm 6.65 \%$ in D2, D3 and D6 and $93.33 \pm 11.54 \%$ in D1. Significant $(P<0.05)$ differences were observed in the treated groups (D2, D3, D4, D5 \& D6) of rohu fed lapsi after 90 days of feeding trials as compared to control (D1) diet fed group. Average initial length of rohu was $2.32 \pm 0.017 \mathrm{~cm}$ in the beginning of the experiment while, highest $15.49 \pm 0.199 \mathrm{~cm}$ length was recorded in D4 diet fed group. In other treated groups the average final length recorded were $13.57 \pm 0.254 \mathrm{~cm}$ (D3), $13.13 \pm 0.412 \mathrm{~cm}$ (D5), $12.02 \pm 0.96 \mathrm{~cm}$ (D6) and $11.42 \pm 0.165$ $\mathrm{cm}$ (D2) in control diet fed group the final length recorded was $10.68 \pm 0.375 \mathrm{~cm}$ (D1). The length gain in all the treated and control groups were $8.36 \pm 0.37 \mathrm{~cm}$ (D1), $9.1 \pm 0.17 \mathrm{~cm}$ (D2), $11.25 \pm 0.25 \mathrm{~cm}$ (D3), $13.17 \pm 0.19 \mathrm{~cm}$ (D4), $10.81 \pm 0.41 \mathrm{~cm}$ (D5) and $9.71 \pm 0.96 \mathrm{~cm}$

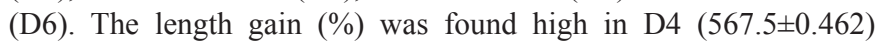
diet fed group followed by D3 (484.8 \pm 0.977$)$, D5 (465.75 \pm 0.794$)$, D6 $(418.01 \pm 0.903), \mathrm{D} 2(392.38 \pm 0.952)$ and D1 $(360.47 \pm 0.902)$. Similarly, a higher $57.43 \%$ increase in length was observed in D4 diet fed group as compared to control D1 diet fed group and the length gain increment in other treated groups were 34.5 (D3), 29.21 (D5), 15.96 (D6), and 8.85 (D2) respectively. Similar results were found in the average final weight and weight gain (\%) of different diets fed groups. The average initial weight was $3.43 \pm 0.11 \mathrm{~g}$ in the beginning of experiment which after 90 days of feeding trials, highest average final weight and average weight gain were recorded in D4 $(22.42 \pm 0.23$ g, $19.45 \pm 0.54 \mathrm{~g}$ ) diet fed group. The average weight gain $\%$ was found high in D4 (567.5 \pm 0.88$)$ diet fed group followed by D3 (484.82 \pm 0.01$)$,
D5 (465.75 \pm 0.77$),$ D6 (418.13 \pm 0.71$), \mathrm{D} 2(392.38 \pm 0.31)$ and D1 (360.47 \pm 0.04$)$. Similarly, a higher $67.5 \%$ increase in weight was observed in D4 diet fed group as compared to control D1 diet fed group and the weight gain increment in other treated groups were 40.2 (D5), 35.64 (D3), 26.66 (D6), and 12.64 (D2) respectively. Significant results were observed in SGR among all the treated and control diet fed groups after 90 days of feeding trial. SGR level was found high inD4 (2.17 \pm 0.019$)$ followed by D5 $(2.00 \pm 0.03)$, D3 (1.97 \pm 0.05$)$, D6 $(1.91 \pm 0.15), \mathrm{D} 2(1.80 \pm 0.021)$ and $\mathrm{D} 1(1.73 \pm 0.06)$ diet fed groups. FCR level was found decreased up to D4 diet fed group but in D5 and D6 it showed a bit increasing trend. The Highest FCR was recorded in control D1 (2.18 \pm 0.03$)$ diet fed group.

\section{Vitamin $\mathbf{C}$ concentration in blood serum, brain and liver}

Vitamin C (L-ascorbic acid) levels of blood serum, brain and liver were also estimated. Significant differences $(\mathrm{P}<0.05)$ were found in the vitamin $\mathrm{C}$ concentration in blood serum and tissues of brain and liver of all the treated diet fed groups in comparison to control diet fed group. The highest vitamin $\mathrm{C}$ concentration in blood serum was observed in D4 diet fed group $(15.38 \pm 0.329 \mu \mathrm{g} / \mathrm{mg})$. In liver also similar trend was recorded. The vitamin C concentration in D4 diet fed group was $191.83 \pm 3.29 \mu \mathrm{g} / \mathrm{mg}$ followed by groups fed with diet D3 $(148.51 \pm 9.07 \mu \mathrm{g} / \mathrm{mg})$, D6 $(142.63 \pm 23.08 \mu \mathrm{g} / \mathrm{mg})$, D2 (136.72 \pm $1.11 \mu \mathrm{g} / \mathrm{mg}), \mathrm{D} 5(135.49 \pm 14.87 \mu \mathrm{g} / \mathrm{mg})$ and the minimum was in D1 $(127.52 \pm 5.80 \mu \mathrm{g} / \mathrm{mg})$ diet fed group. In the brain highest vitamin C concentration was $91.197 \pm 3.59 \mu \mathrm{g} / \mathrm{mg}$ in D4 diet fed group followed by $81.86 \pm 0.02$ (D3), $78.93 \pm 0.97$ (D2), $65.86 \pm 0.01$ (D5), $59.02 \pm 06$ (D6) and $57.373 \pm 3.318$ (D1) (Table 2).

Table 2 Concentrations of vitamin C in blood serum, liver and brain of rohu fed varied doses of lapsi up to 90 days of trial

\begin{tabular}{llllllll}
\hline S.N. & Parameters & DI & D2 & D3 & D4 & D5 & D6 \\
\hline I & Vit-C S & $7.54 \pm 0.661$ & $12.16 \pm 1.169$ & $12.52 \pm 0.617$ & $15.38 \pm 0.329$ & $14.46 \pm 0.320$ & $13.34 \pm 0.320$ \\
2 & Vit-CL & $110.52 \pm 5.80$ & $136.72 \pm 1.11$ & $148.51 \pm 9.07$ & $191.83 \pm 3.29$ & $135.49 \pm 14.87$ & $142.63 \pm 23.08$ \\
3 & Vit-C B & $57.373 \pm 3.318$ & $78.930 \pm 1.977$ & $81.867 \pm 3.241$ & $91.197 \pm 3.598$ & $65.867 \pm 9.111$ & $59.020 \pm 4.064$
\end{tabular}

Vit-C S,Vitamin C in Blood serum;Vit-C,Vitamin C in Brain;Vit-C L,Vitamin C in Liver

Values are provided as mean $\pm \mathrm{SE} ; \mathrm{n}, 3$

\section{Discussion}

Many herbs are used in aquatic animals including fish to promote growth. ${ }^{14,15}$ All the rohu fed with diets supplemented with ethanol extract of lapsi fruit showed better growth than control group. The maximum growth was observed in group fed with D4 diet. These results indicates that rohu needs vitamin $\mathrm{C}$ supplemented diet for better growth which agreed well with the works of GouillousCoustans et al., ${ }^{8}$; Shiau \& Hus $^{16}$ and Wang et al., ${ }^{17}$ Several species of fish including rainbow trout and Korean rockfish fed with diet containing sufficient vitamin $\mathrm{C}$ showed better growth. ${ }^{18,19}$ The recommended ascorbic acid need for optimum growth of channel catfish is 10 to $25 \mathrm{mg}$ per kg of diet. ${ }^{20}$ Cyprinus carpio $^{8}$ and for newly hatched Cirrhinus mrigala ${ }^{21}$ is 650 to $700 \mathrm{mg}$ per kg diet. Growth rates in fishes depend upon the amount of Vitamin $\mathrm{C}$ present in the diet. The fish fed with diet containing more vitamin $\mathrm{C}$ grew more and the fish fed with diet containing fewer vitamins $\mathrm{C}$ grew less. The fish feed with diet without vitamin $\mathrm{C}$ showed less growth. ${ }^{22}$ The herbal drugs promote growth, boost stress resistance boosters and prevent infections. Most fishes, including rohu, cannot synthesis vitamin $\mathrm{C}^{23}$ due to lack of L-gulonolactone oxidase. ${ }^{24}$ Stickney et al., ${ }^{25}$ reported supplementation of $50 \mathrm{mg}$ of ascorbic acid in one kilogram diet resulted in maximum weight gain without any deficiency signs in blue tilapia (Oreochromis aureus). Similarly $79 \mathrm{mg}$ ascorbic acid in one kilogram diet was the required level for maximum weight gain of hybrid tilapia (Oreochromis niloticus $x$ Oreochromis aureus. ${ }^{26}$ Many studies have shown that fish with high concentration of vitamin $\mathrm{C}$ in tissues can tolerate ambient pollution and are better resistant to 
bacterial infections. ${ }^{27}$ Tilapia exposed to sub lethal dose of mercury showed weight gain, increase specific growth rate and survival rate when fed with diet containing high level of ascorbic acid. ${ }^{28}$ Increase in the amount of lapsi extract in the diets directly relates with the concentration of vitamin $\mathrm{C}$ in the blood serum, brain and liver of rohu. Fish with more vitamin $\mathrm{C}$ in tissues are healthier than with less vitamin $C .{ }^{29}$ Vitamin $\mathrm{C}$ concentration in blood serum, brain and liver were significantly $(\mathrm{P}<0.05)$ higher in the rohu fed with $\mathrm{D} 4$ diet and other treated groups and minimum in control diet fed group. The diet without vitamin $\mathrm{C}$ supplementation decreased the specific growth rate $\left(0.32 \%\right.$ day $\left.^{-1}\right)$ in juvenile $O$. karongae and this is in accordance with studies conducted by Ai et al., ${ }^{30}$ who also observed decreasing specific growth rate in sea bass (Scophthalmus maximus) fed with vitamin $\mathrm{C}$ deficient diet. The concentration of vitamin $\mathrm{C}$ in various tissues is related to the vitamin $\mathrm{C}$ taken along with diet. Vitamin $\mathrm{C}$ concentration is brain and liver is high concentrations of vitamin C. ${ }^{31}$

\section{Conclusion}

Labeo rohita, an indigenous major carp, has high market demand in Nepal. Lapsi is an indigenous Himalayan medicinal herb and pulp of its fruits having rich in antioxidant properties has high medicinal values. L. rohita cannot make vitamin C. The finding of this study along with other findings from different researchers generally recognized that the lapsi fruit extract in feed of rohu increase survival rate, power to resist stressful environmental situations and accelerate growth. For successful culture of L.rohita in ponds $400 \mathrm{mg}$ lapsi extract in one $\mathrm{kg}$ feed is recommended. ${ }^{32-34}$

\section{Acknowledgements}

None.

\section{Conflict of interest}

Author declares that there is no conflict of interest.

\section{References}

1. Paudel KC, Pieber K, Klumpp R. Evaluation of lapsi tree Choerospondias axillaris (Roxb.) for fruit production in Nepal, Bodenkultur-Wien and Munchen. 2003;54(1):3-10.

2. Shah DJ. Ascorbic acid (vitamin C) content of Lapsi- pulp and peel at different stage of maturation, Res Bull, (2035 BS, Food Research Section, HMGN, Department of Food and Agriculture Marketing Services, Kathmandu). 1978

3. Zhou J, Huang J, Song XL. Applications of immunostimulants in aquaculture. Marine Fish Research. 2003;24:70-79.

4. Labh SN, Shakya SR, Kayasta BL. Extract of Medicinal lapsi Choerospondias axillaris (Roxb.) exhibit antioxidant activities during in vitro studies. Journal of Pharmacognosy and Phytochemistry. 2015;4(3):194-197.

5. Chunmei Li, Jie He, Yonglin Gao, et al. Preventive Effect of Total Flavones of Choerospondias axillaris on chemia/Reperfusion-Induced Myocardial Infarction-Related MAPK Signaling Pathway. Cardiovasc Toxicology. 2014;14:145-152.

6. Lim C, Klesius PH, Li MH, et al. Intraction between dietary levels of iron and vitamin $\mathrm{C}$ on growth, hematology, immune response and resistance of channel catfish (Ictalurus punctatus) to Edwardsiella ictaluri challenge. Aquaculture. 2000;185:313-327.
7. Anderson JS, Sunderland R. Effect of extruder moisture and dryer processing temperature on vitamin $\mathrm{C}$ and $\mathrm{E}$ and astaxanthin stability. Aquaculture. 2002;207:137-149.

8. Gouillou-Coustans, Bergot MFP, Kaushik SJ. Dietary ascorbic acid needs for common carp (Cyprinus carpio) larvae. Aquaculture. 1998;453-461.

9. Dabrowski K. Absorption of ascorbic acid and ascorbic sulfate and ascorbate metabolism in stomachless fish, common carp. Journal of Comparative Physiology B. 1990;160:549-561.

10. Sato P, Nishikimi M, Udenfriend S. Is L-gulonolactone-oxidase the only enzyme missing in animals subject to scurvy? Biochem Biophys Res Commun. 1976;71:293-299.

11. Dabrowski K. Ascorbic acid in aquatic organisms. CRC press; 2001288 p.

12. Dabrowski K. Hinterleitner, S. Applications of a simultaneous assay of ascorbic acid, dehydroascorbic acid and ascorbic sulphate in biological materials. Analyst. 1989;114:83-87.

13. Duncan DB. Multiple range and multiple ' $F$ ' tests. Biometrics. 1955:11:1-42.

14. Citarasu T, Sekar RR, Babu MM, et al. Developing Artemia enriched herbal diet for producing quality larva in Peneaus monodon. Asian Fish Science. 2002;15:21-32.

15. Immanuel G, Citarasu T, Sivaram V. Delivery of HUFA, probionts and biomedicine through biocapsulated Artemia as a means to enhance the growth and survival and reduce the pathogenicity in shrimp Penaeus monodon post larvae. Aquacult Internet. 2007;15:137-152.

16. Shiau SY, Hsu TS. Quantification of vitamin C requirement for juvenile hybrid tilapia, Oreochromis niloticus, with L-ascorbyl-2-monophasphate $\mathrm{Na}$ and L-ascorbyl-2-monophasphate Mg. Aquaculture. 1999;175:317326.

17. Wang XJ, Kim KW, Bai SC, et al. Effects of the different levels of dietary vitamin $\mathrm{C}$ on growth and tissue ascorbic acid changes in parrot fish (Oplegnathus fasciatus). Aquaculture. 2003;215:21-36.

18. Lee KJ, Bai SC. Different dietary levels of L-ascorbic acid affect growth and vitamin $\mathrm{C}$ status of juv nile Korean rockfish (Sebastes schegeli). Aquaculture. 1998;161:475-477.

19. Lee $\mathrm{SH}$, Oe T, Blair IA. Vitamin $\mathrm{C}$ induced decomposition of lipid hydroperoxides to endogenous genotoxins. Science. 2001;292:20832086.

20. Mustin WG, Lovell RT. Na-L-ascorbyl-2-monophosphate as a source of vitamin C for channel catfish. Aquaculture. 1992;105:95-100.

21. Mahajan CL, Agrawal NK. Comparative tissue ascorbic acid studies in fishes. J Fish Biol. 1980;17:135-141.

22. Lee KJ, Dabrowski, K. Interaction between vitamins $\mathrm{C}$ and $\mathrm{E}$ affects their tissue concentrations, growth, lipid oxidation and deficiency symptoms in yellow perch (Perca flavescens). British Journal of Nutrition. 2003;89: 589-596.

23. Chatterjee IB. Evolution and the biosynthesis of ascorbic acid. Science. 1973;182:1271-1272.

24. Wilson, RP. Absence of ascorbic acid synthesis in channel catfish, Ictalurus punctatus and blue catfish, Ictalurus frucatus. Comp Biochem Physiol B. 1973;46(3):635-638.

25. Stickney RR, Mc Geachin RB, Lewis DH, et al. Response of Tilapia aurea to dietary vitamin C. Journal of the World Mariculture Society. 1984; $15: 179-185$. 
26. Shiau SY, Jan FL. Dietary Ascorbic acid requirement of Juvenile tilapia Oreochromis niloticus $\times$ O. aurea. Bulletin of the Japanese Society of Scientific Fisheries.1992;58:671-675.

27. Li Y, Lovell RT. Elevated levels of dietary ascorbic acid increases immune response in channel catfish. Journal of Nutrition. 1985;115:123-131.

28. Abdel-Tawwab M, Shalaby AME, Ahmed MH. Effect of supplement dietary L-ascorbic acid (vitamin C) on mercury intoxication and growth performance of Nile tilapia (Orechromis niloticus L.). Annals of Agric Sci Moshtoher. 2001;39(2):961-973.

29. Halver JE. Recent advances in vitamin nutrition and metabolism. In Cowey CB, Mackie AM, editors. Nutrition and Feeding in Fish. New York: Academic Press;1985:415-429.

30. Ai QH, Mai KS, Li HT, et al. Effects of dietary protein to energy ratios on growth and body composition of juvenile Japanese sea bass, Lateolabrax japonicus. Aquaculture. 2004;230:509-516.
31. Gabaudan J, Verlhac V. Biological efficacy of Rovimix Stay-C as a source of vitamin C for Salmonids. Proceeding of the International Symposium on Cultivation of Atlantic Salmon, Bergen. 1992;16-20.

32. AOAC. Official methods of analysis. 16th ed. Arlington, Virginia, USA;1995.

33. Sandnes K. Vitamin C in fish nutrition-a review. Fisk Dir Skr Ser Ernaering. 1991;4:3-32.

34. Tolbert BM. Ascorbic acid metabolism and physiological function International Journal of Veterinary, Nutrition and Research. 1979;19:127-142. 